\title{
A COMISSÃo INTERNACIONAL DE DIÁLOGO CATÓLICO-PENTECOSTAL E O CONTEXTO BRASILEIRO
}

\author{
THE INTERNATIONAL COMMISSION ON CATHOLIC-PENTECOSTAL DIALOGUE \\ AND THE BRAZILIAN CONTEXT
}

André Luís da Rosa ${ }^{1}$

Resumo: Dentre os principais conflitos religiosos presentes no Brasil, as dificuldades de relação entre católicos e pentecostais ocupam um lugar relevante por se tratarem das duas maiores tradições cristãs do país. Assim, esta pesquisa possui como objetivo apresentar algumas questões fundamentais sobre o diálogo católico-pentecostal no Brasil. Primeiramente, busca-se compreender como se configura atualmente o catolicismo e o pentecostalismo, pois são os sujeitos deste diálogo. No segundo momento, faz-se uma análise da Comissão de Diálogo Católico-Pentecostal do Vaticano em relação à realidade brasileira, focando nas dificuldades existentes entre católicos e pentecostais para que se estabeleça um diálogo ecumênico.

Palavras-chave: Catolicismo, pentecostalismo, diálogo.

Abstract: Among the main religious conflicts in Brazil, the difficulties of relations between Catholics and Pentecostals occupy an important place because they are the two major Christian traditions in the country. This way, this research aims to present some fundamental questions about Catholic-Pentecostal dialogue in Brazil. First of all, we try to understand how Catholicism and Pentecostalism are nowadays, since they are the subjects of this dialogue. In the second moment, an analysis is made of the Vatican's Catholic-Pentecostal Dialogue Commission regarding the Brazilian reality, focusing on the difficulties that exist between Catholics and Pentecostals in order to establish an ecumenical dialogue.

Key-words: Catholicism, Pentecostalism, dialogue.

\section{1) Introdução}

Dois dados têm sido constantes nas pesquisas sobre o fenômeno religioso no Brasil: a diminuição dos católicos e o crescimento acelerado dos (neo)pentecostais (TEIXEIRA, 2013, p. 23). O Brasil é, ao mesmo tempo, o maior país católico e pentecostal do mundo, todavia, estes grupos não possuem significativas iniciativas de diálogo. Ao contrário, na maioria dos casos possuem uma postura fechada ao ecumenismo, e vivem em uma situação combativa, marcada por diversos preconceitos (ROSA, 2016, p. 1). Assim, quase todo brasileiro, religioso ou estudioso do fenômeno religioso, sabe, ao menos de modo geral, que católicos e pentecostais são tidos como rivais no Brasil. A Igreja Católica, com os protestantes históricos,

\footnotetext{
${ }^{1}$ Mestre em Ciências das Religiões pela Faculdade Unida de Vitória. Especialista em Ciências da Religião pela Universidade Cândido Mendes. Licenciado em Ensino Religioso pela Faculdade Paulista São José. Bacharel em Filosofia pela Faculdade São Luiz. Membro da Rede Latino-Americana de Estudos Pentecostais - Núcleo Brasil (RELEP). Contato: andreldarosa@hotmail.com
} 
ortodoxos e outras religiões, possui algum diálogo e até ações sociais comuns (por exemplo: Campanha da Fraternidade Ecumênica), mas, com os pentecostais ainda não.

Nesse sentido, esta pesquisa possui como objetivo apresentar algumas questões fundamentais para a compreensão do diálogo católico-pentecostal no Brasil. Primeiramente, busca-se compreender como se configura atualmente o catolicismo e o pentecostalismo, pois são os sujeitos deste diálogo. No segundo momento, faz-se uma análise da Comissão de Diálogo Católico-Pentecostal do Vaticano em relação à realidade brasileira, focando nas dificuldades existentes entre católicos e pentecostais para que se estabeleça um diálogo ecumênico.

\section{2) Catolicismos e pentecostalismos no Brasil}

Não é a intenção desta pesquisa fazer um levantamento histórico do catolicismo e do pentecostalismo no Brasil. Para alcançar-se o objetivo de compreender o diálogo entre estas duas expressões do cristianismo, basta um olhar sobre como os mesmos configuram-se atualmente no contexto brasileiro. Constatando assim, a primeira complexidade para o diálogo entre ambos: a pluralidade; que nestes casos parece ilimitada, a ponto de quando ouvir-se falar de um diálogo católico-pentecostal, poder questionar-se: qual pentecostalismo está dialogando com qual catolicismo? A Igreja católica difunde a ideia de ser una, mas as ciências sociais constatam diversos catolicismos, por vezes até rivais entre si.

O pentecostalismo apresenta-se como um grupo multidenominacional, mas as ciências sociais evidenciam que apesar de serem diferentes pentecostalismos, eles mantêm diversas continuidades em suas teologias e práticas pastorais. Assim, constata-se que a diversidade em ambos se dá de forma diferente: o catolicismo trata-se de uma instituição dividida em diversas espiritualidades, e o pentecostalismo de uma espiritualidade dividida em diversas instituições.

O catolicismo romano é ainda preponderante, mas perde a cada década sua centralidade, configurando-se como a "religião da maioria dos brasileiros", e não mais a “religião dos brasileiros" (TEIXEIRA, 2013, p. 23). Para Antônio Flávio PIERUCCI (2013, p. 50), o catolicismo em declínio indisfarçável é o traço mais forte e determinante a marcar o panorama atual do campo religioso brasileiro. Mas foi sobretudo a partir dos anos 1980 que a porcentagem de católicos foi declinando cada vez mais: 90\% em 1980, 83,3\% em 1991, $73,8 \%$ em 2000 e 64,6\% em 2010, ou seja, atualmente 123.280.172 de declarantes católicos (TEIXEIRA, 2005, p. 15).

Porém, para além dos dados do Censo, ao analisar a Igreja Católica no Brasil, as recentes pesquisas possuem um dado em comum: é impossível falar de um tipo ideal de 
catolicismo. Ele apresenta-se, segundo Carlos Rodrigues BRANDÃO (2013, p. 97), como uma religião que atinge atualmente os "limites quase extremos de pluripossibilidades de pertença e de multialternativas de vivência individual". Todavia, esta pluralidade é abrigada sobre um desejo de universalidade hegemônica da instituição católica, como se depreende da clássica análise do filósofo Antônio GRAMSCI:

\begin{abstract}
cada religião, mesmo a católica (ou melhor, especialmente a católica, primeiramente pelos seus esforços em permanecer unitária "superficialmente" para não se despedaçar em igrejas nacionais e em estratificações sociais) é na realidade uma multiplicidade de religiões distintas e muitas vezes contraditórias: há um catolicismo dos camponeses, um catolicismo dos pequenos burgueses e operários da cidade, um catolicismo de mulheres e um catolicismo de intelectuais, também ele variegado e desconexo (1978, p. 114).
\end{abstract}

Gramsci é um filósofo italiano, mas sua análise aplica-se perfeitamente ao Brasil, pois, para Cecília Loreto MARIZ (2011, p. 53), a queda na proporção de católicos parece estar sendo acompanhada por um relativo reavivamento religioso, e mais ainda, por uma intensificação da diversidade na experiência do ser católico. Esta diversidade no interior da Igreja Católica não é captada pelo Censo, pois este questiona a confissão religiosa: "qual a sua religião?”, mas não faz a pergunta: “como você vive a sua religião?”.

No caso do catolicismo, para BRANDÃO (2013, p. 91), tão importante quanto a pergunta: "você é católico?" é a pergunta: “e como você vive o seu ser católico?", pois, conforme ele, "mais do que qualquer outra alternativa cristã de fé pessoal, culto de crença e prática de vida, o catolicismo de hoje abre-se a todas as alternativas" (BRANDÃO, 2013, p. 97). Podendo-se sintetizar esta ideia com a imagem da socióloga Brenda CARRANZA (2011, p. 74) de a Igreja Católica como "um imenso guarda-chuva sob o qual alberga-se uma imensa diversidade de expressões religiosas".

Por isso, para compreender a atual identidade da Igreja Católica romana no Brasil, não se pode perder de vista o fato de que: "o desejo de catolicidade permanece, mas se confronta sempre mais com uma ampla variedade de modos de sentir e de ser católicos na sociedade contemporânea" (PACE, 2013, p. 147). Assim, podemos elencar diversas formas de catolicismos no Brasil, como, por exemplo, um catolicismo popular, voltado para a prática das devoções populares aos santos; um catolicismo libertador, engajado em causas sociais e uma reflexão teológica crítica; um catolicismo carismático, que difunde a doutrina do batismo no Espírito Santo e dos carismas, especialmente o das línguas e da cura; e um catolicismo tradicionalista, que denominasse defensor da tradição católica em oposição à modernização da fé. 
Mas, além destas linhas gerais do catolicismo, há uma imensa quantidade de congregações religiosas, associações, grupos, movimentos eclesiais, comunidades de vida e de aliança, cada uma vivenciando o catolicismo com características próprias e, ainda, dentro destas expressões eclesiais do catolicismo há diversidade no modo de ser católico. Por exemplo: em uma mesma congregação ou comunidade religiosa pode haver membros mais adeptos do movimento carismático ou das CEBs, complexificando a tal ponto a identidade católica, que se torna impossível uma classificação completa dos modos de ser católico.

Quanto ao pentecostalismo, pode-se afirmar que ele é hoje um fenômeno global, multicultural, multidimensional e multiconfessional (WOLFF, 2015, p. 7). Por isso, o termo pentecostal é genérico, não se referindo a um só segmento da fé evangélica, mas a vários grupos e expressões originadas no escopo do protestantismo mundial (SANCHES, 2015, p. 146). A pluralidade parece ser uma nota própria desta manifestação religiosa, pois a intenção originária do Movimento Pentecostal não era a de fundar uma nova instituição, mas, como afirma o pentecostal Roger CABEZAS (1996, p. 32): “o pentecostalismo é mais que uma doutrina (uma confissão), é uma maneira de viver e experimentar a fé cristã que emergiu do seio de diversas tradições confessionais".

Assim problematiza Ronaldo de ALMEIDA:

\begin{abstract}
nos sistemas classificatórios mais frequentes o pentecostalismo brasileiro é considerado pertencente ao meio evangélico ao lado dos protestantes históricos e em oposição ao catolicismo no interior do cristianismo. Mas como classificar, então, os protestantes 'renovados' e os carismáticos católicos que se apropriam de dimensões do pentecostalismo como a experiência extática da glossolalia e, no caso dos católicos, a conversão individual tipicamente evangélica com ênfase na subjetividade e na emotividade? [...] Em resumo, o pentecostalismo extrapola suas fronteiras institucionais assim como incorpora mecanismos de funcionamento de religiões fora do campo cristão (2011, p. 111).
\end{abstract}

Por este motivo, o pentecostalismo é um movimento diversificado por natureza e assumiu diversas configurações desde suas origens. Segundo Gedeon Freire de ALENCAR:

nunca existiu um pentecostalismo no singular, mas pentecostalismos no plural, desde suas origens americanas e, também - e bem mais anteriores -, dos movimentos de santidade e pietismos europeus. O Movimento da Rua Azusa, em Los Angeles, se tornou a grande referência no século XX, mas não foi o único. Muito pouco deste pentecostalism black chegou até nós (2013, p. 15).

O crescimento não planejado estrategicamente do pentecostalismo, mas espontâneo, para Regina Fernandes SANCHES (2016, p. 14), demonstrou ser rico em possibilidades, justificando-se a fluidez deste movimento, o que impõe grandes desafios de identificação ou de construção de identidades no pentecostalismo. Os pentecostalismos consideram-se obra do 
Espírito Santo, que age sobre todos, assim, valoriza-se a experiência subjetiva. Cada pessoa é motivada a buscar sua própria experiência, como analisa Esdras Costa BENTHO: "não há como transferir, reproduzir ou transmitir a mesma experiência a outros. Cada um deve ter sua própria experiência de batismo no Espírito Santo" (2015, p. 99). Ainda, verifica-se que os pentecostalismos são multidimensionais, pois possuem a capacidade de impregnar as mais variadas estruturas sociais e religiosas, e transterritorial, uma vez que o ser pentecostal assume características específicas conforme o continente ou o país (WOLFF, 2015, p. 8).

Esta diversidade de pentecostalismos tem sido classificada por diversos autores, a partir das linhas comuns, de data de surgimento ou doutrinas, das denominações. Segundo Regina Fernandes SANCHES (2016, p. 13), tem-se, no Brasil, expressões pentecostais provenientes diretamente do Movimento de Santidade, como o próprio pentecostalismo da Rua Azusa, bem como as Igrejas geradas no Brasil, classificadas como pentecostalismo histórico. Há também as Igrejas carismáticas ou de "renovação", formadas após a pentecostalização de grupos de dentro das Igrejas evangélicas históricas fundadas no esforço missionário dos séculos XIX e XX.

Já a autora Dafne Sabanes PLOU (2002, p. 87), apresenta quatro maneiras diferentes das igrejas pentecostais formarem-se na América Latina: os movimentos que nasceram nas denominações históricas; os movimentos que surgiram por obra de missionários independentes, como Francescon; as Igrejas pentecostais que nasceram por obra de migrantes latino-americanos ao sul dos EUA, que regressaram a seus países pregando a mensagem pentecostal; e os movimentos iniciados pela obra de pessoas do próprio país.

O teólogo Bernardo CAMPOS (2002, p. 73) apresenta quatro tendências básicas no pentecostalismo latino-americano:

1- o pentecostalismo de expansão internacional, com forte influência do pentecostalismo americano;

2- o pentecostalismo de ramificação nacional, em desacordo aberto com o fundamentalismo norte-americano;

3- o neopentecostalismo, mais próximo do catolicismo do que do protestantismo evangélico, mas ainda oscilante e indefinido, e

4- os "movimentos de cura divina", aos quais denomino isopentecostalismo, porque estão em sintonia com algumas particularidades do pentecostalismo clássico, mas cuja identidade, ainda em processo de desenvolvimento, parece ser de natureza diferente (CAMPOS 2002, p. 73).

Comentando as classificações realizadas do pentecostalismo, Regina Fernandes SANCHES (2015, p. 146) ressalta que são esforços teóricos, todavia, não abarcam integralmente todas as formas e representações que se autodeclaram pentecostais, apenas apresentam, em linhas gerais, uma distinção entre as principais correntes do movimento. 
Muitos, a partir da diversidade de pentecostalismos, falam de uma identidade comum entre eles, para que se possa afirmar uma identidade pentecostal genérica. Teologicamente, para Roger HAIGHT (2012, p. 523-525), quatro doutrinas básicas fundamentam a fé pentecostal: a de que Jesus é o Senhor (Jo 2,16); que Jesus batiza no Espírito Santo (At 2,4); que Cristo cura (Tg 5,14-15); e a quarta diz respeito à segunda vinda de Cristo (1Ts 4,16-17).

HAIGHT ainda ressalta a centralidade da bíblia no pentecostalismo e que a doutrina do Espírito Santo constitui-se no foco central da fé pentecostal. Há ainda diversas tônicas comuns aos pentecostalismos, segundo observa Elias WOLFF (2015, p. 8), como: a relativização das mediações para o acesso à graça que cura, liberta e salva; a expressão emocional da fé; tendências à massificação no processo de evangelização, sobretudo pelo recurso midiático; tendências a espiritualizar o concreto da existência cotidiana; a fé experiencial, pois mais que uma doutrina o que importa é a experiência.

\section{3) A Comissão Internacional de Diálogo Católico-Pentecostal}

Após uma breve compreensão da atual configuração do catolicismo e do pentecostalismo no Brasil, fazem-se agora alguns apontamentos sobre a Comissão Internacional de Diálogo Católico-Pentecostal e a realidade brasileira. Apesar de esta comissão ser oficial para a Igreja Católica, no Brasil, a CNBB não realizou nenhum esforço de diálogo com os pentecostais, e, quanto às igrejas pentecostais brasileiras, elas não possuem nenhuma representação na comissão, demonstrando a difícil relação entre católicos e pentecostais nestas terras.

Depois da realização do Concílio Vaticano II, a Igreja Católica iniciou uma nova experiência em sua história: os diálogos bilaterais. Os interlocutores da Igreja Católica no diálogo teológico oficial pertencem a quase todas as tradições do cristianismo: Igrejas ortodoxas, Comunhão Anglicana, Federação Luterana Mundial, Aliança Reformada Mundial, Conselho Metodista Mundial, Aliança Batista Mundial, Conselho Ecumênico de Igrejas (CEI), e, o objeto desta pesquisa, o Movimento Pentecostal (NAVARRO, 1995, p. 182).

O diálogo oficial da Igreja Católica com os pentecostais possui suas raízes efetuadas durante 1969-1970 por alguns membros de Igrejas Pentecostais com o então Secretariado Romano para a Unidade dos Cristãos. Segundo Juan Bosh NAVARRO (1995, p. 189), entre aqueles, deve-se destacar a figura do reverendo David du Plessis, notável pentecostal africano 
e observador no Concílio Vaticano II. Em 1971, foi criado um comitê misto que propôs um programa de estudos a serem realizados durante um quinquênio, divididos em seis fases ${ }^{2}$.

Diferente das outras comissões, o diálogo católico-pentecostal possui algumas peculiaridades: ele não se trata de um diálogo bilateral em sentido estrito, como o diálogo católico-luterano, mas de um diálogo misto ou multilateral, pois nele estabelece-se um diálogo entre a Igreja Católica e diversas denominações pentecostais ${ }^{3}$.

Portanto, elas não representam o todo do Movimento Pentecostal, mas algumas denominações particulares. Ainda há alguns que participam deste diálogo, do grupo dos pentecostais, que não possuem qualquer autorização oficial de suas denominações, por isso não são representantes oficiais (ROBECK, 2008, p. 13). Segundo Marcial MAÇANEIRO (2015, p. 102), o diálogo não se define estritamente pela oficialidade, mas pela espiritualidade, através da profissão comum da fé trinitária e da fraternidade.

Também, diferente das outras comissões de diálogo, o diálogo entre pentecostais e católicos não é marcado por um cisma, mas parte de uma nova forma de experimentar a fé cristã (MAÇANEIRO, 2013, p. 24). Porém, é interessante levar em consideração que, hoje, após quinhentos anos da reforma protestante, depois de uma longa história de excomunhões e perseguições, o diálogo entre católicos e luteranos, por exemplo, já produziu frutos de reflexão e cooperação conjuntas. Já as atitudes de preconceitos e perseguições entre a Igreja Católica e os pentecostais ainda é recente, e mais, atual, o que possui grande peso sobre um possível futuro ecumênico.

Outra das principais características do Diálogo Internacional Católico-Pentecostal é a de considerar a experiência do novo pentecostes, ou do batismo no Espírito Santo, como sua abordagem básica, por ser determinante para a identidade comum das Igrejas participantes. Para o padre Marcial MAÇANEIRO (2013, p. 22), as denominações participantes da experiência pentecostal envolvidas no diálogo apresentam elementos comuns e convergentes

\footnotetext{
${ }^{2}$ As fases do Diálogo Internacional Católico-Pentecostal foram organizados do seguinte modo: $1^{\text {a }}$ fase: o batismo no Espírito Santo e a iniciação cristã; relação entre Escritura e Tradição; pessoa, dons e carismas (19721976); $2^{\text {a }}$ fase: a fé, a experiência religiosa e o falar em línguas; o papel de Maria (1977-1982); $3^{\text {a }}$ fase: perspectivas sobre Koinonia e comunhão cristã (1985-1989); 4ª fase: evangelização, proselitismo e testemunho comum (1991-1997); 5a fase: tornar-se cristão: conversão, iniciação cristã, batismo no Espírito Santo e discipulado (1998-2006); $6^{\mathrm{a}}$ fase: Carismas na Igreja: significado espiritual, discernimento e implicações pastorais (MAÇANEIRO, 2013, p. 13-14).

${ }^{3}$ Desde 1972, participaram as seguintes Igrejas e/ou associações confessionais: Igreja Apostólica do México (México), Igreja Assembleia de Deus (EUA), Igreja Internacional do Evangelho Quadrangular (América do Norte), Igreja Pentecostal de Santidade (EUA), Igreja Pentecostal da Polônia (Polônia), Igreja de Deus (América do Norte), Assembleias Pentecostais do Canadá (Canadá), Assembleias de Deus Independentes (EUA), Comunhão Internacional de Igrejas Carismáticas (EUA), Movimento Pentecostal da Suécia (Suécia), Movimento Visão de Futuro (Argentina), Igreja Bíblia Aberta (EUA), Igreja Missão Pentecostal (Chile), Igreja do Deus da Profecia (EUA e Alemanha), Igreja Pentecostal de Cristo (Iugoslávia), Igreja Evangélica Internacional (Itália), Missão de Fé Apostólica (Âfrica do Sul), Comunidade Pentecostal na Holanda (Holanda), Igreja Reformada (Holanda), Igreja Pentecostal Elim (Reino Unido), Igreja do Pentecostes (África, Europa e Américas), Conselho de Igrejas Pentecostais de Gana (Gana) e Igreja Católica Apostólica Romana (MAÇANEIRO, 2015, p. 106).
} 
como: a conversão, a confissão de Jesus Cristo como Senhor e Salvador, o batismo no Espírito Santo, a efusão de dons e carismas, cultos de louvor, ardor evangelístico-missionário. Estes são elementos partilhados por evangélicos e católicos que experimentaram o novo pentecostes.

Patrício Merino BEAS (2012, p. 593-594), ainda ressalta três características essenciais para a compreensão desta comissão: 1- que ela não busca realizar disputas teológicas entre católicos e pentecostais, mas esclarecer o sentido teológico das doutrinas e práticas de fé, tal como entende e vive cada tradição; 2- a comissão não busca uma unidade estrutural entre católicos e pentecostais, e sim fomentar o respeito e entendimento mútuo, desenvolvendo uma concepção de ecumenismo que possa ser melhor entendida e acolhida pela tradição pentecostal; 3- o aporte teórico deste diálogo é somente a Palavra de Deus e o recurso aos Padres da Igreja (escritos do período patrístico).

Todavia, NAVARRO (1995, p. 191) também apresenta as divergências mais notáveis que foram surgindo durante o diálogo. Entre elas destaca-se: o tema da recepção ou impossibilidade de recepção do Espírito Santo por parte dos não-cristãos; a recusa por parte dos pentecostais dos princípios filosóficos e teológicos da crítica das formas, porque esses princípios contrariam a inspiração total da Escritura; e os problemas da mariologia e dos ministérios na Igreja. Também Camilo TRIANO (2010, p. 76), ao analisar o diálogo, aponta como um desafio à carência de unidade no pentecostalismo, sendo notória a falta de coesão, dificultando uma postura clara e oficial diante do catolicismo. O relatório final da primeira fase do diálogo apresenta uma grande limitação deste diálogo, admitindo

não representar a posição oficial das Igrejas pentecostais ou da Igreja Católica, mas,
sobretudo, o conteúdo das discussões. Embora sejam resultado de estudos sérios e
do diálogo de pessoas responsáveis, as resoluções não comprometem nenhuma das
Igrejas ou tradições, com as posturas teológicas aqui expressas, devendo essas serem
submetidas a elas para um uso e reação oportunos (NAVARRO, 1995, p. 190).

Afunilando para a realidade brasileira, para refletir sobre a aplicabilidade do diálogo católico-pentecostal, deve-se tomar consciência, como constatou Gedeon ALENCAR, em sua análise sociológica da comissão, dos seguintes dados: são mais de 40 anos de atividades, com a participação de quase 200 pessoas. Mas, o continente Latino-Americano é minoria, representado apenas por oito membros (três católicos e cinco pentecostais), enquanto são 109 da América do Norte, ficando evidente o domínio dos EUA e da Europa e a insignificante participação dos latino-americanos.

Do Brasil, o maior país católico e pentecostal do mundo, foram apenas dois representantes: o pastor Luís Carlos Pinto, da Igreja do Evangelho Quadrangular, em 1991, 
cuja sua participação se deu a convite de um amigo americano, não representando sua Igreja e, atualmente, encontrando-se afastado de sua denominação. Do lado católico houve a participação de um padre, Marcial Maçaneiro, mas somente na sexta fase do diálogo (20102016). Também houve a participação do missionário canadense, Walter Robert Mc Alister, que fundou a Igreja de Vida Nova, no Rio de Janeiro, porém, representando o Brasil e os EUA (ALENCAR, 2015, p. 126-127).

Estes dados podem sugerir que a falta de motivação em iniciar uma caminhada ecumênica entre católicos e pentecostais no Brasil deve-se à falta de participantes brasileiros na Comissão Internacional, de ambos os lados, ou, simplesmente, podem levar a constatar que não há interesse em que se haja um diálogo entre a Igreja Católica e as Igrejas Pentecostais no Brasil, sendo que nele a Igreja Católica tem perdido sua hegemonia à custa do crescimento do pentecostalismo. Todavia, o fato é que católicos e pentecostais no Brasil são indiferentes ou inimigos.

Segundo ROBECK (2008, p. 4), um professor de estudos latino-americanos, Phillip Berryman, passou um ano em vários países da América Latina, e observou que no Brasil os pentecostais e os católicos tendem a simplesmente ignorar-se mutuamente. O conhecimento que possuem um do outro está baseado em meros estereótipos ou provém de leituras muito desatualizadas. Como resultado, quando falam uns dos outros, com frequência cometem equívocos.

\section{1) Da abertura católica ao diálogo com os pentecostais}

Quanto à abertura do catolicismo ao diálogo com o pentecostalismo no Brasil, podemse fazer algumas observações: primeiramente, ressalta-se que o Concílio Vaticano II, marco da abertura ecumênica do catolicismo, quando produziu o Decreto Unitatis Redintegratio (documento católico sobre o ecumenismo), não possuía consciência de que o cenário cristão mundial sofreria uma drástica mudança, em um curto espaço de tempo, com a explosão do pentecostalismo.

Quando o Decreto foi elaborado, os padres conciliares tinham em mente apenas os cristãos ortodoxos e os oriundos da reforma protestante, sendo que, o pentecostalismo, apesar de ter surgido no início do século $\mathrm{XX}$, começou a ganhar visibilidade e expressão apenas depois da segunda guerra mundial. Portanto, aos olhos deste pesquisador, mesmo que o Vaticano II tenha sido uma atualização pastoral para a Igreja Católica, faz-se necessário, neste seu cinquentenário, uma reatualização, uma contextualização da teologia ecumênica do 
catolicismo perante o fenômeno pentecostal, que traz novos desafios para a pastoral contemporânea.

Outro fato é que, como afirmou o teólogo Leonardo BOFF (1982, p. 59) em seu livro Igreja, carisma e poder, na Igreja Católica há uma deficiência entre sua teoria e sua prática. Aplicando esta afirmação ao ecumenismo católico-pentecostal, pode-se constatar uma deficiência entre a teoria e a prática da própria instituição, não apenas dos fiéis. Os documentos produzidos pelas comissões bilaterias do Vaticano possuem pouca receptividade nas comunidades católicas. A maioria dos fiéis nem se quer sabem de sua existência (por vezes, nem mesmo bispos e padres tem conhecimento dos mesmos). Ainda mais se tratando da comissão de diálogo com os pentecostais.

Dos cinco documentos, apenas dois foram traduzidos para o português ${ }^{4}$ e ainda são descontextualizados da realidade sociorreligiosa brasileira. Diante desta falta de coerência entre a teoria dos documentos católicos e sua aplicação prática, cabe uma indagação de Ricardo MARIANO (1996, p. 76): que tipo de ecumenismo é este em que a Igreja Católica propõe diálogo a interlocutores que considera perigosos, propagadores de falsas promessas e que crescem, supostamente, à custa da ignorância e ingenuidade do povo?

De fato, foi assim que a Igreja Católica encarou o crescimento do pentecostalismo: um desafio, um problema a ser combatido, uma ameaça. Ela, ao mesmo tempo, apresenta uma proposta ecumênica e um firme propósito de manter sua hegemonia religiosa no Brasil; propõe-se a dialogar com seus concorrentes, mas quer recuperar seu rebanho perdido (MARIANO, 1996, p. 76).

A CNBB ficou em silêncio sobre os pentecostais até o ano de 1991, quando assumiu publicamente a evasão de fiéis e o êxito dos pentecostais, chamados por eles como seitas, como um problema para a Igreja Católica (ORO, 1996, p. 97). Ela dividiu seus trabalhos pastorais em seis dimensões, e uma delas é a Comissão de Ecumenismo e Diálogo InterReligioso. Porém, mesmo que a CNBB diga reconhecer a diversidade religiosa e respeitar a liberdade religiosa como inerente à condição humana, muitos membros da hierarquia, até mesmo os papas João Paulo II e Bento XVI, parecem não perceber no pentecostalismo um movimento religioso positivo que se expande por seus próprios méritos e que possui direito à existência.

O pesquisador Ari Pedro ORO coletou uma série de afirmações provindas da CNBB, que demonstram essa atitude como: "o êxito das chamadas seitas é visto como um grave

\footnotetext{
${ }^{4}$ CONSELHO PONTIFÍCIO PARA A PROMOÇÃO DA UNIDADE DOS CRISTÃOS. Diálogo católicopentecostal. São Paulo: Paulinas, 1999. E: COMISSÃO INTERNACIONAL DE DIÁLOGO CATÓLICOPENTECOSTAL. Tornar-se cristão: inspiração da Escritura e dos textos da patrística com algumas reflexões contemporâneas. Brasília: CNBB, 2010.
}

[revista Último Andar (ISSN 1980-8305), n. 32, dezembro de 2018] 
problema", "as seitas são um fenômeno da crise", "as seitas são mais movimentos que igrejas e praticam o aliciamento por todos os meios", "a Igreja sofre hoje com o proselitismo fanático e interesseiro de algumas seitas" (1996, p. 92-93).

Dentre diversos discursos do Papa João Paulo II sobre as seitas na América Latina, apresenta-se aqui um que demonstra a preocupação da hierarquia: "vejo que nos diversos países da América Latina o problema número um é, cada vez mais, o problema das seitas. [...] Isto deve constituir um motivo a mais de preocupação pastoral, que nos leva a propor e planejar uma ação evangelizadora"s.

Também o papa Bento XVI (2008, p. 278), em 2007, no Brasil, durante a abertura da $5^{\text {a }}$ conferência de todo episcopado latino-americano, ainda apresentou as seitas como um desafio à Igreja Católica, dizendo: “percebe-se, contudo um certo enfraquecimento da vida cristã no conjunto da sociedade e da própria pertença à Igreja Católica, devido ao secularismo, ao hedonismo, ao indiferentismo e ao proselitismo de numerosas seitas". No documento de Aparecida, publicado em 2008, os bispos de toda a América Latina afirmaram: "os desafios que o mundo de hoje apresenta à Igreja de Cristo, entre outros: o êxodo de fiéis para seitas e outros grupos religiosos" (CELAM, 2007, p. 93).

Uma iniciativa da CNBB de conhecer melhor os pentecostais foi por meio de uma série de três seminários realizados entre 1991 e 1994, com o tema: A Igreja Católica diante do pluralismo religioso no Brasil. Todavia, segundo Gedeon ALENCAR (2015, p. 123), eles não foram realizados com um intuito ecumênico ou para estabelecer uma relação de amizade e caminhada fraterna, mas os pentecostais entraram na pauta como problema. Dele, resultaram três estudos publicados ${ }^{6}$, nos quais se analisam todos os fenômenos religiosos presentes no Brasil e sua relação com a pastoral Católica.

Neles, o pentecostalismo é interpretado, em linhas gerais, como um movimento que possui suas raizes na crise da modernidade e que seu crescimento se dá por uma falha da pastoral católica e das demais Igrejas tradicionais. No final de cada estudo apresentam-se algumas sugestões pastorais. Apenas no segundo volume há uma referência ao diálogo com os pentecostais: "é urgente que a Igreja Católica e as demais Igrejas do CONIC abram canais de diálogo com as Igrejas Pentecostais" (CNBB, 1993, p. 128). Nos demais números fica evidente que a Igreja Católica no Brasil possui muito mais abertura para o diálogo com as religiões afro-brasileiras do que com os pentecostais. Também se insiste em todos os estudos

\footnotetext{
5 JOÃO PAULO II. Discurso de S. João Paulo II, aos bispos do Peru em sua visita ad limina-Vaticano, junho de 1988 - L'Osservatore Romano, 23 (1988). Disponível em: <http://www.acidigital.com/seitas/papa.ht m>. Acesso: 28 abr. 2017.

${ }^{6}$ CNBB. A Igreja Católica diante do pluralismo religioso no Brasil I. São Paulo: Paulinas, 1991. - CNBB. A Igreja Católica diante do pluralismo religioso no Brasil II. São Paulo: Paulus, 1993. - CNBB. A Igreja Católica diante do pluralismo religioso no Brasil III. São Paulo: Paulus, 1994.
}

[revista Último Andar (ISSN 1980-8305), n. 32, dezembro de 2018] 
e nas sugestões pastorais a renovação pastoral da Igreja Católica, denominada "nova evangelização", tendo por objetivo controlar a evasão de seus fiéis.

Um dado importante é que o Brasil é o único país latino-americano onde a Igreja Católica possui participação ativa em um conselho nacional de Igrejas, o CONIC (Conselho Nacional de Igrejas Cristãs) (PLOU, 2002, p. 62), sendo que em outros ela participa apenas como observadora. Dele, além da Igreja Católica, participam algumas Igrejas Protestantes históricas. Ambas perseguiram os pentecostais em suas origens. Por isso, o principal organismo ecumênico do país, diante do pentecostalismo, não enxergou nele um interlocutor capaz de diálogo, de se estabelecer uma caminhada fraterna, mas um desafio comum para as Igrejas históricas.

Elias WOLFF (2002, p. 64-65), membro da comissão teológica do CONIC, no ano de 2002 constatou esta atitude do conselho diante dos pentecostais, dizendo tem procurado aproximar seus componentes numa maior compreensão do pentecostalismo, que pode ser visto como um desafio à proclamação da mensagem das Igrejas históricas, ou como um fator de aproximação delas em torno de uma prática pastoral comum. Os desafios comuns são: internos às Igrejas, pois o espaço não atingido pela ação pastoral destas é o ocupado pelos pentecostais; e externo às Igrejas, como a situação geográfica não alcançada pelas Igrejas históricas que são tomados pelos pentecostais, especialmente os lugares marginalizados. Também a crise cultural, o vazio espiritual e o relativismo religioso são tidos como elementos que estão na raiz do crescimento do pentecostalismo. Neste ponto, cabe a pergunta de ALENCAR (2014, p. 221): “os pentecostalismos brasileiros são antiecumênicos ou os ecumenismos são antipentecostais?".

\section{2) Da abertura pentecostal ao diálogo com os católicos}

Quanto à abertura do pentecostalismo ao diálogo com o catolicismo no Brasil, também podem ser feitas algumas observações. Segundo o sociólogo José Bittencourt FILHO (1996, p. 235): "exceto no Brasil, o pentecostalismo clássico latino-americano sustem uma participação ativa no movimento ecumênico". Para corroborar com esta afirmação sobre a abertura ecumênica do pentecostalismo no Brasil, pode-se recorrer a duas falas do cientista da religião ALENCAR, pesquisador do ecumenismo pentecostal. Na primeira, de cunho testemunhal, ele relata:

em um congresso de sociologia na Costa Rica, tomei um susto quando conheci um pastor assembleiano peruano, um dos mais importantes, que era também o principal 
líder ecumênico em seu país. Assembleiano ecumênico é escasso no Brasil, mas não na América Latina (ALENCAR, 2015, em entrevista) 7 .

Na segunda, em entrevista a este pesquisador, ALENCAR analisa:

o mais irônico é que as ADs no Brasil e demais grupos pentecostais sempre se
referem ao ecumenismo e, direto ou indiretamente, à Igreja Católica como uma ação
do anticristo, a prostituta do apocalipse; as tratativas ecumênicas seriam apenas uma
estratégia diabólica para a dominação do anticristo. Mas, outros pentecostais, em
outros países, não têm essa "doutrina", inclusive, na CDVP [Comissão Internacional
de Diálogo Católico Pentecostal] em que 23 pastores assembleianos já participaram.
Como brinco com amigos pastores assembleianos antiecumênicos, se o ecumenismo
é ação do anticristo, esqueceram de avisar as ADs americanas (ALENCAR, 2016,
em entrevista) ${ }^{8}$.

Naturalmente, como comenta MARIANO (1996, p. 71), os pentecostais, que no passado sofreram perseguição religiosa, sendo vítimas de preconceitos e discriminação, desconfiam das intenções dos novos interlocutores, sobretudo da Igreja Católica. Demonstrando o sentimento anticatólico presente no pentecostalismo latino-americano, David MESQUIATI (2013, p. 19) registra em seu artigo sobre o Fórum Pentecostal LatinoAmericano e Caribenho de 2012, que quando se abordou o tema do ecumenismo, alguns pentecostais questionaram: "se vamos considerar os católicos e protestantes históricos como cristãos e irmãos, a quem iremos pregar na América Latina?”.

Analisando este sentimento anticatólico pentecostal no Brasil, Volney José BERKENBROCK (2014, p. 138-140) explica que a maioria dos membros das Igrejas Pentecostais no Brasil provém do catolicismo. Isto pelo simples fato de a maioria da população ser ainda católica. Não significando, todavia, que sejam católicos religiosamente engajados. Ao adentrar em uma Igreja Pentecostal, o fiel passa por uma experiência de conversão, que o faz reorganizar seu modo de vida, seus valores. Esta nova ordem religiosa se constrói em contraposição ou em distanciamento de seu universo religioso anterior. BERKENBROCK chama a este movimento de identidade na diferença.

A maioria das Igrejas Pentecostais construiu sua identidade religiosa no Brasil, justamente tendo como base a oposição, a diferenciação e o distanciamento em relação à Igreja Católica. Do ponto de vista institucional, era para as Igrejas nascentes uma questão de sobrevivência marcar sua diferença para com o mundo católico e, para os novos convertidos mostrarem sua nova maneira de ser. Tenta-se provar justamente isso: não se é mais católico.

\footnotetext{
${ }^{7}$ ALENCAR, Gedeon Freire de. A Assembleia de Deus e a matriz pentecostal brasileira - entrevista com o sociólogo Gedeon Alencar. Disponível em: <http://www.genizahvirt ual.com/ 2015/12/a-assembleia-de-deus-em atriz.html>. Acesso: 19 mar. 2017.

${ }^{8}$ ALENCAR, Gedeon Freire. Igreja Católica e Assembleia de Deus. Santa Catarina, jan. 2016. Entrevista concedida a André Luís da Rosa.
} 
Neste fator, ainda segundo BERKENBROCK, o pentecostalismo brasileiro é certamente diferente do pentecostalismo dos EUA, pois lá o elemento de necessidade de contraposição ou de distanciamento do mundo católico não foi tão decisivo porque a maioria dos pentecostais não são oriundos do catolicismo. Assim, como consequência, ao se converter e assumir a identidade pentecostal brasileira, todas as atitudes anteriores, tidas como errôneas ou pecaminosas, são relacionadas com a antiga identidade religiosa, ou seja, eram atitudes de católicos, que devem ser evitadas.

Como consequência desta questão da identidade na diferença, cria-se a mentalidade de que todo pentecostal é um cristão, mas nem todo cristão é um pentecostal. Esta afirmação encerra a dificuldade de que há diferença entre a fé cristã ordinária e a fé pentecostal, sendo que: a primeira é confessada de maneira débil, a segunda de uma maneira total; a primeira é simples e superficial, a segunda é completa e profunda; a primeira é fruto do esforço humano, a segunda é sobrenatural (GÓMEZ, 2008, p. 89-90).

Analisando o discurso pentecostal acerca do catolicismo, Juan Usma GÓMEZ (2008, p. 81), apresenta as seguintes considerações: 1- um pentecostal, por ser pentecostal, considera-se um verdadeiro cristão - um católico, por ser católico, não é necessariamente um cristão; 2- um pentecostal tem a certeza da salvação porque aceitou a Jesus em seu coração - a maioria dos católicos não são salvos, pois dificilmente se escuta dizerem: "Jesus é meu Senhor e Salvador"; 3- um pentecostal tem uma vida reta e santa - um católico não, possui uma ética laxista; 4- um pentecostal sabe quando, como e onde encontrou o Senhor (em outras palavras, sabe quando se converteu) - um católico sabe quando foi batizado, mas não consegue identificar o momento de conversão a Jesus Cristo; 5- um pentecostal sabe que foi tocado por Deus e espera sua volta iminente - nem todos os católicos se interessam pela missão e, certamente, não acreditam na vinda iminente de Jesus; 6- um pentecostal tem que ser membro ativo de sua congregação - um católico pode passar no anonimato em sua comunidade.

Assim, a formação da identidade na diferença dificulta a movimentação das Igrejas Pentecostais em relação a um diálogo ecumênico com a Igreja Católica, pois, por enxergarem no catolicismo algo mau, devem convidar os católicos a desligarem-se de suas estruturas eclesiais, para os salvar (WOLFF, 1999, p. 32). Logo, como estabelecer relações ecumênicas com aqueles que se tem o projeto de converter? A partir disto, difunde-se a ideia de que o ecumenismo católico é uma artimanha do anticristo, e que ao dialogarem com a Igreja Católica, o passo seguinte será aceitar a dominação romana, tornando os pentecostais e os protestantes apenas ramificações do catolicismo (BURKETT, 2000, p. 55). 
Apenas para ilustrar, Elias WOLFF (1999, p. 32) apresenta a fala de um pastor assembleiano, que retrata um projeto missionário pentecostal: "se mantivermos as altas taxas de crescimento registradas pela nossa Igreja desde o início [...] chegará o dia em que ninguém mais dirá que o Brasil é o maior país católico do mundo”. E o pastor Caio Fábio, fundador da AEVB (Associação Evangélica Brasileira), um órgão extremamente eclético que reunia Igrejas protestantes históricas, pentecostais e movimentos carismáticos na década de noventa, sendo questionado sobre o CONIC, em 1999, respondeu: "no dia que a AEVB tomasse essa decisão [filiar-se ao CONIC], ela perderia oitenta por cento de seus associados. O que temos junto à Igreja Católica? Apenas uma relação de diálogo informal" (CESAR; SHAULL, 1999, p. 140). Assim, como propor ecumenismo aos líderes pentecostais com suas Igrejas crescendo sobretudo às custas da Igreja Católica? (MARIANO, 1996, p. 72).

\section{4) Considerações finais}

Apresentou-se, neste breve artigo, um mapeamento das principais dificuldades para o estabelecimento de uma comissão oficial de diálogo entre a Igreja Católica e as Igrejas Pentecostais no Brasil, como a que há no Vaticano desde 1972. Mas, mesmo com tantos desafios, algumas iniciativas de encontro estão surgindo. Encerra-se apresentando alguns sinais que podem indicar pequenos passos rumo ao ecumenismo católico-pentecostal no Brasil, como: a iniciativa de algumas comunidades de vida católicas ligadas à espiritualidade carismática que tem se aberto ao diálogo com os pentecostais em suas sedes, como a Comunidade Adorai, em Varginha, Minas Gerais, e, no Rio de Janeiro, a Comunidade Bom Pastor, a Comunidade de Jesus e a Comunidade Coração Novo; a participação de um brasileiro na Comissão Internacional de Diálogo Católico Pentecostal, o padre Marcial Maçaneiro; a realização do Fórum Pentecostal Latino Americano e Caribenho no Brasil, em 2015, sobre o ecumenismo, com a publicação da obra Pentecostalismos e unidade; a publicação, no ano de 2015, da Revista Brasileira de Diálogo Ecumênico e Inter-religioso, a Caminhos de Diálogo, que é produzida pela Comissão Episcopal de Pastoral para o Ecumenismo e o Diálogo Inter-Religioso da CNBB, com o dossiê: Pentecostalismo e ecumenismo: interpelações para o diálogo; além da realização, desde 2008, do ENCRISTUS, um evento de ecumenismo espiritual entre católicos e pentecostais, porém ainda pequeno e com pouca representação. 


\section{Referências bibliográficas:}

ALENCAR, Gedeon Freire de. A Assembleia de Deus e a matriz pentecostal brasileira entrevista com o sociólogo Gedeon Alencar. Disponível em: <http://www.genizahvirt ual.com/ 2015/12/a-assembleia-de-deus-e-matriz.html>. Acesso: 19 mar. 2017.

. Igreja Católica e Assembleias de Deus: diálogo ecumênico seria uma relação do pescoço com a guilhotina?. In: OLIVEIRA, David Mesquiati de (Org.). Pentecostalismos e unidade. São Paulo: Fonte Editorial, 2015.

- Pentecostalismos e ecumenismos: Deus e o diabo se (des)entendendo na terra do sol. Caminhos, Goiânia, vol. 12, n. 1, p. 220-239, jan./jul. 2014.

Prefácio. In: OLIVEIRA, David Mesquiati de (Org.).

Pentecostalismos e transformação social. São Paulo: Fonte editorial, 2013.

Igreja Católica e Assembleia de Deus. Santa Catarina, jan.

2016. Entrevista concedida a André Luís da Rosa.

ALMEIDA, Ronaldo de. A expansão pentecostal: circulação e flexibilidade. In: TEIXEIRA, Faustino; MENEZES, Renata (Orgs.). As religiões no Brasil: continuidades e ruptura. 2. ed. Petrópolis: Vozes, 2011.

BEAS, Patricio Merino. Contenidos teológicos para um diálogo católico-pentecostal: hacia um testimonio común del Evangelio. Teología y vida, Universidad Católica De La Santíssima Concepción, vol. 53, p. 575-602, 2012.

BENTHO, Esdras Costa. Entre a emoção e a razão: a experiência pneumatológica dos pentecostais clássicos. Caminhos de Diálogo: Revista de Diálogo Ecumênico e InterReligioso, Brasília, n. 4, a. 3, p. 91-102, 2015.

BENTO XVI. Homilia do papa Bento XVI na missa de inauguração da V conferência geral do episcopado da América Latina e do Caribe. In: CONFERÊNCIA GERAL DO EPISCOPADO LATINO-AMERICANO E DO CARIBE V, 2007, Aparecida. Documento de Aparecida. 7. ed. Brasília: CNBB, 2008.

BERKENBROCK, Volney José. Il Pentecostalismo e il dialogo ecumenico con il cattolicesimo. Studi Ecumenici, Veneza, a. 32, n. 2, p. 135-151, Jan-Jun, 2014.

BITTENCOURT FILHO, José. Por uma nova teologia Latino-americana: a teologia da proscrição. São Paulo: Paulinas, 1996.

BOCK, Carlos Gilberto. O ecumenismo eclesiástico em debate: uma análise a partir da proposta ecumênica do CONIC. São Leopoldo: Sinodal, 1998.

BOFF, Leonardo. Igreja, carisma e poder: ensaios de eclesiologia militante. 3. ed. Petrópolis: Vozes, 1982.

BRANDÃO, Carlos Rodrigues. Catolicismo. Catolicismos?. In: TEIXEIRA, Faustino; MENEZES, Renata (Orgs.). Religiões em movimento: o Censo de 2010. Petrópolis: Vozes, 2013. 
BURKETT, Bill. Pentecostais ou carismáticos: um chamado ao verdadeiro pentecostes. 3. ed. Tradução: Paulo Ferreira. Rio de Janeiro: CPAD, 2000.

CAMPOS, Bernardo. Da reforma protestante à pentecostalidade da igreja. São Leopoldo: Sinodal; Quito: CLAI, 2002.

CARRANZA, Brenda. Catolicismo midiático. In: TEIXEIRA, Faustino; MENEZES, Renata (Orgs.). As religiões no Brasil: continuidades e ruptura. 2. ed. Petrópolis: Vozes, 2011.

CASCO, Miguel Angel; CABEZAS, Roger; MANRÍQUEZ, Samuel Palma. Pentecostais, libertação e ecumenismo. São Leopoldo: CEBI, 1996. p. 32.

CESAR, Waldo; SHAULL, Richard. Pentecostalismo e futuro das igrejas cristãs: promessas e desafios. Petrópolis: Vozes, 1999.

CNBB. A Igreja Católica diante do pluralismo religioso no Brasil I. São Paulo: Paulinas, 1991.

. A Igreja Católica diante do pluralismo religioso no Brasil II. São Paulo: Paulus, 1993. 1994.

. A Igreja Católica diante do pluralismo religioso no Brasil III. São Paulo: Paulus,

COMISSÃO INTERNACIONAL DE DIÁLOGO CATÓLICO-PENTECOSTAL. Tornar-se cristão: inspiração da Escritura e dos textos da patrística com algumas reflexões contemporâneas. Brasília: CNBB, 2010.

CONSELHO PONTIFÍCIO PARA A PROMOÇÃO DA UNIDADE DOS CRISTÃOS. Diálogo católico-pentecostal. São Paulo: Paulinas, 1999.

GÓMEZ, Juan Usma. El pentecostalismo en Latinoamérica: identidad y perspectiva ecumênica. Teologia em Questão, Taubaté, a. 7, n. 14, p. 79-93, 2008.

GRAMSCI, Antônio. Concepção dialética da história. 2. ed. Rio de Janeiro: Civilização Brasileira, 1978.

HAIGHT, Roger. A comunidade cristã na história: eclesiologia comparada. Vol. 2. São Paulo: Paulinas, 2012.

IBGE. Censo Demográfico 2010: características gerais da população, religião e pessoas com deficiência. Rio de Janeiro: IBGE, 2010.

JOÃo PAULO II. Discurso de S. João Paulo II, aos bispos do Peru em sua visita ad liminaVaticano, junho de 1988 - L'Osservatore Romano, 23 (1988). Disponível em: $<$ http://www.acid igital.com/seitas/papa.ht m>. Acesso: 28 abr. 2017.

MAÇANEIRO, Marcial. Uma aproximação ao diálogo internacional católico-pentecostal. Cultura teológica, São Paulo, a. 21, n. 83, p. 11-31, jul./dez., 2013.

Na Unidade do Espírito Santo: observações sobre o Diálogo

Internacional Católico-Pentecostal. In: OLIVEIRA, David Mesquiati de (Org.). Pentecostalismos e unidade. São Paulo: Fonte Editorial, 2015.

MARIANO, Ricardo. Diálogo ecumênico entre católicos, protestantes e pentecostais no Brasil. Cultura teológica, São Paulo, a. 4, n. 16, p. 69-77, jul./set., 1996. 
MARIZ, Cecília Loreto. Catolicismo no Brasil contemporâneo: reavivamento e diversidade. In: TEIXEIRA, Faustino; MENEZES, Renata (Orgs.). As religiões no Brasil: continuidades e ruptura. 2. ed. Petrópolis: Vozes, 2011.

NAVARRO, Juan Bosh. Para compreender o ecumenismo. São Paulo: Loyola, 1995.

OLIVEIRA, David Mesquiati de. Os pentecostais e a mesa de debate: o caso do fórum pentecostal Latino-Americano e Caribenho (FPLyC). Azusa: Revista de Estudos Pentecostais, Joinville, v. 4, n. 2, p. 9-22, 2013.

ORO, Pedro Ari. Avanço pentecostal e reação católica. Petrópolis: Vozes, 1996.

PACE, Vicenzo. Habemus Papam: Jorge Mário Bergoglio frente à crise sistêmica da Igreja una, santa, católica e romana. Estudos de Religião, São Bernardo do Campo, v. 27, n. 2, p. 141-158, jul/dez, 2013.

PIERUCCI, Antônio Flávio. O crescimento da liberdade religiosa e o declínio da religião tradicional: a propósito do Censo de 2010. In: TEIXEIRA, Faustino; MENEZES, Renata (Orgs.). Religiões em movimento: o Censo de 2010. Petrópolis: Vozes, 2013.

PLOU, Dafne Sabanes. Caminhos de unidade: itinerário do diálogo ecumênico na América Latina. São Leopoldo: Sinodal, 2002.

ROBECK, Cecil M. Diálogo católico romano-pentecostal: desafíos y lecciones para vivir juntos. Instituto teológico FIET, 2008. Disponível: <http://www.fiet.com.ar/articulo/ catedra_petrecca_2008_cecil_robe ck.pdf>.Acesso: 02 nov. 2017.

SANCHES, Regina Fernandes. Desafios identitários para a questão da unidade no pentecostalismo. In: OLIVEIRA, David Mesquiati de (Org.). Pentecostalismos e unidade. São Paulo: Fonte Editorial, 2015.

Prefácio por uma teóloga protestante. In: CUNHA, Carlos.

Hermenêutica biblica libertadora: encontro entre católicos e pentecostais. São Paulo: Garimpo, 2016.

TEIXEIRA, Faustino. Faces do catolicismo brasileiro contemporâneo. Revista USP, São Paulo, n. 67, p. 14-23, set./nov., 2005.

O censo de 2010 e as religiões no Brasil: esboços de apresentação. In:

TEIXEIRA, Faustino; MENEZES, Renata (Orgs.). Religiões em movimento: o Censo de 2010. Petrópolis: Vozes, 2013.

TRIANO, Camilo Andrés Acosta. Perspectivas ecuménicas entre el catolicismo y el pentecostalismo. Bogotá: Pontifícia Universidad Javeriana, 2010.

WOLFF, Elias. Caminhos do ecumenismo no Brasil: história, teologia, pastoral. São Paulo: Paulus, 2002.

Editorial. Caminhos de Diálogo: Revista Brasileira de Ecumenismo e Diálogo Inter-Religioso, Brasília, n. 4, a. 3, p. 7-9, 2015.

. O ecumenismo no Brasil: uma introdução ao pensamento ecumênico da CNBB. São Paulo: Paulinas, 1999. 